\title{
Pathophysiological and Genetic Aspects of Vascular Calcification
}

\author{
Luis Fernando Escobar Guzman (D), Cristian Andres Escobar Guzman, \\ and Neuza Helena Moreira Lopes ${ }^{1}$ \\ ${ }^{1}$ Heart Institute (InCor), University of São Paulo Medical School, São Paulo, Brazil \\ ${ }^{2}$ Department of Pathology, University of São Paulo Medical School, São Paulo, Brazil \\ Correspondence should be addressed to Luis Fernando Escobar Guzman; luisguzman709@gmail.com
}

Received 18 October 2019; Revised 17 February 2020; Accepted 23 March 2020; Published 14 April 2020

Academic Editor: Elena Cavarretta

Copyright (c) 2020 Luis Fernando Escobar Guzman et al. This is an open access article distributed under the Creative Commons Attribution License, which permits unrestricted use, distribution, and reproduction in any medium, provided the original work is properly cited.

\begin{abstract}
Recent evidence suggests that vascular calcification is an independent cardiovascular risk factor (CRF) of morbidity and mortality. New studies point out the existence of a complex physiopathological mechanism that involves inflammation, oxidation, the release of chemical mediators, and genetic factors that promote the osteochondrogenic differentiation of vascular smooth muscle cells (VSMC). This review will evaluate the main mechanisms involved in the pathophysiology and genetics modulation of the process of vascular calcification. Objective. A systematic review of the pathophysiology factors involved in vascular calcification and its genetic influence was performed. Methods. A systematic review was conducted in the Medline and PubMed databases and were searched for studies concerning vascular calcification using the keywords and studies published until 2020/01 in English. Inclusion Criteria. Studies in vitro, animal models, and humans. These include cohort (both retrospective and prospective cohort studies), case-control, cross-sectional, and systematic reviews. Exclusion Criteria. Studies before 2003 of the existing literature.
\end{abstract}

\section{Introduction}

According to data from the World Health Organization, there was a 17\% decline in mortality from 2005 to 2015 . Currently, the prevalence of cardiovascular diseases (CDs) remains high, 7.4\% for men and 5.3\% for women, due to the highest prevalence of cardiovascular risk factors (CRFs) and aging [1].

Recent evidence shows that there is a high prevalence of vascular calcification (VC) in atherosclerosis, diabetes, and chronic kidney disease, standing out as an independent CRF of morbidity and mortality $[2,3]$. Data from the MESA study show that the calcium score (CAC), the main marker of CV, was associated with a gradual increase in risk events. In the multivariate analysis, considering the traditional risk factors, CAC $>300$ was associated with a nearly 7 -fold increased risk (CI 95\% 2.93-15.99) for cardiovascular outcomes compared to those with a zero CAC [4].

Depending on the histological arterial site, different types of VC can be distinguished: intimal calcification or medial artery calcification.
Intimal calcification is associated with atherosclerotic plaque formation comprises fibrous cap, necrotic/lipid nucleus, cholesterol crystals, inflammatory cells that are prone to erosion, rupture and obstruction of blood flow, reduced organ perfusion, and ischemic syndromes $[5,6]$.

Medial artery calcification, also called Mönckeberg calcification, represents the pathological deposition of calcium and phosphate in the medial layer of the arteries. This vascular calcification is considered less directly associated with inflammation. It can cause stiffness of the vascular wall, leading to changed arterial hemodynamic properties. This results in an increased chance of hypertension and left ventricular hypertrophy and aggravates the risk of cardiac events $[5,6]$.

In the past, $\mathrm{VC}$ was considered being the consequence of a passive degenerative process, but recent studies suggest the existence of a complex physiopathological mechanism still in elucidation that involves inflammation, oxidation, and release of chemical mediators. This mediator promotes or inhibits differentiation of vascular smooth muscle cells 


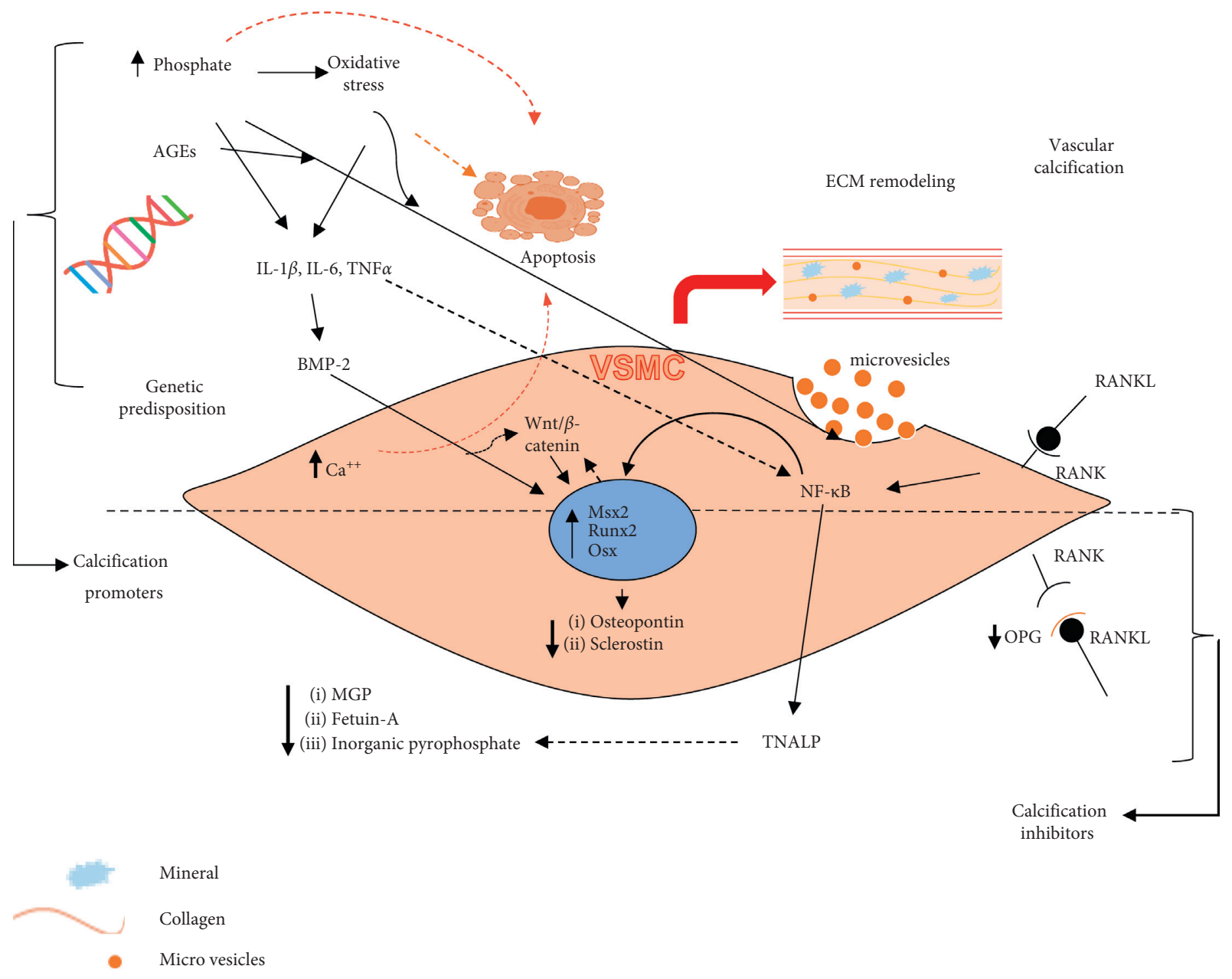

FIGURe 1: Pathophysiological mechanisms which promote cellular differentiation and vascular calcification. AGEs, advanced glycation end products; VSMC, vascular smooth muscle cell; BMP, bone morphogenetic protein; Runx2, runt-related transcription factor 2; Msx2, msh homeobox 2; IL-1 $\beta$, interleukin-1beta; IL-6, interleukin-6; TNF $\alpha$, tumor necrosis factor alpha; NF- $\kappa \mathrm{B}$, nuclear factor kappa-light-chainenhancer of activated B cells; RANK, receptor activator of nuclear factor kappa-B; RANKL, receptor activator of nuclear factor kappa-B ligand; ECM, extracellular matrix; OPG, osteoprotegerin; MGP, matrix gla protein; TNALP, tissue nonspecific alkaline phosphatase.

(VSMCs) in osteo/chondroblastic cells. There is also evidence of genetic factors involved in this process $[7,8]$.

In this review, we will appraise the main cellular mechanisms, chemical mediators, and genetic components that involve the pathophysiology of vascular calcification (Figure 1).

\section{Pathophysiology}

2.1. Vascular Calcification Inducing Factors Inflammation, Oxidative Stress, and Lipids. It is recognized that VC is associated with a chronic and low-grade inflammatory state, exacerbated by nonvascular conditions such as metabolic alterations, autoimmune diseases, environmental factors (pollution), cancer, and obesity [7-10].

This inflammatory process was related to the increase of serum levels of TNF-alpha IL-1b promoting the stimulation of tissue nonspecific alkaline phosphatase (TNAP) activity, the enzyme that hydrolyzes pyrophosphate ions, which are potent inhibitors of mineralization and, therefore, can induce calcification regardless of the main transcription factor for osteoblasts RUNX2, in VSMC [7, 11]. Moreover, IL-6 was significantly associated with coronary artery calcification and cardiovascular mortality in patients with impaired renal function [12].

Studies have reported that increased oxidative stress is related to VC in vitro; recently, Zhao et al. showed that mitochondrial reactive oxygen species (ROS) are the major source of ROS production and are essential for the Pitriggered phenotype switch of SMCs from a contractile to an osteogenic form [13].

Proinflammatory proteins include C-reactive protein (CRP) synthesized during inflammatory processes mainly by hepatocytes. Also, they are expressed by other cell types including local production in vascular tissue by VSMCs [14]. An in vitro study discloses a novel direct role of CRP during vascular calcification. CRP induces cellular oxidative stress and activates procalcific intracellular signaling pathways promoting osteo/chondrogenic transdifferentiation of VSMCs in vitro by the increased expression of TNAP and activity of the enzyme Fc fragment of IgG receptor IIa [15]. 
Oxidized LDL (oxLDL) plays a crucial role in the development of VC. The suggested mechanism is a reduction of prostacyclin production and the reduction of cyclooxygenase expression induced by the sustained increase of intracellular calcium. Those changes lead to the rupture of the glycocalyx monolayer integrity that causes endothelial cell apoptosis and the inflammatory process [16].

HDL plays a protective role in atherosclerosis by taking part in the process known as reverse cholesterol transport. In this process, it is believed that the existence of anti-inflammatory and antioxidant properties, probably dependent on the proteins, transported in the HDL particle, such as the enzyme paraoxonase and the reduction of cytokines with consequent attenuation of the osteogenic differentiation induced by oxidized LDL in vascular cells [17]. However, it was observed that patients with established coronary artery disease could have dysfunctional HDL production caused by posttranslational modification of apoA or by the reduction of HDL production induced by microRNAs [18].

2.2. Extracellular Vesicles: Exosomas. Extracellular vesicles are derived from different kinds of cells and classified into 3 classes by origin and size: (1) microvesicles $(100-500 \mathrm{~nm})$, which originate from cell membrane evaginations, (2) exosomes $(40-100 \mathrm{~nm})$, which have the origin of intracellular organelles, and (3) apoptotic bodies $(\sim 1,000 \mathrm{~nm})$, which are generated during programmed cell death [19].

It has been suggested that, during cellular osteochondrogenic differentiation, exosomes are released by VSMC from intracellular multivesicular bodies induced by the production of sphingomyelin phosphodiesterase 3 in response to environmental stress of calcium [20]. The serine protein encoded by the SORT1 gene is associated also with vascular calcification. It was localized in humans and mouse atheromas promoting in vitro the formation of microcalcifications and extracellular vesicles stimulating the alkaline phosphatase release [21].

Other factors associated with exosome formation are the annexins (Anx 6) in the VSMC and Anx 5 in the macrophages that comprise a class of calcium-dependent proteins that mediate cellular processes such as exocytosis and endocytosis. They also participate in regulating inflammation, coagulation, and fibrinolysis [22-24].

2.3. Runt-Related Transcription Factor 2 (Runx2). RUNX2 is the main transcription factor in vascular calcification, and its activity is subjected to regulation by phosphorylation events mediated by kinases and by nuclear translocation, DNAbinding capacity, and interaction with transcriptional cofactors. Runx2 regulates the expression of genes related to osteoblasts, such as osterix, receptor activator of nuclear factor kappa- $\beta$ ligand (RANKL), and type I collagen [25-28].

Tang et al. showed that cells isolated from the middle layer of the vessel wall are expressed as markers Sox17, Sox $10, S 100 \beta$, and neural medium filament polypeptide and differentiated into CML-like cells and later into osteoblastic cells [29]. In an animal model, with SM22-Cre mice with Runx2 exon 8 floxed, the inhibition of receptor activator of nuclear factor kappa- $\beta$ ligand (RANKL) was observed. RANKL was associated with decreased macrophage infiltration and formation of osteoclast-like cells in the aortic wall [30]. However, in other work using Runx2 knockout mice, no reduction in RANKL expression, macrophage infiltration, or atherosclerotic lesion size was observed compared to the control group. Instead, it was found a decrease in the lesion mineralization, besides the substantially decreased expression of osteocalcin, alkaline phosphatase, and chondrocyte maturation [31].

2.4. Bone Morphogenetic Proteins (BMPs). BMPs are a group of proteins expressed by myofibroblasts, and they belong to the family of transforming growth factor-beta. BMPs are known for their important roles during embryogenesis and in the maintenance and repair of bones and other tissues in adults. The most known one is the BMP2 that has osteogenic activities that were related to oxidative stress, inflammation, and hyperglycemia [32]. The mechanism of stimulation would be mediated by the expression of Runx 2 and by the induction of apoptosis of vascular smooth muscle cells, an event that starts vascular calcification [33]. BMPs also bind to type II and type I serine-threonine kinase receptors (bone morphogenetic protein receptor-IA (BMPRIA), BMPR-IB, activin receptor-like kinase-2 (ALK-2), and ALK1) to form complexes that regulate the phosphorylation of Smad1/5/8 and then combine with Smad4 protein. They together translocate to the nucleus where they are involved in the transcription of genes related to osteoblast differentiation, including ERK (extracellular regulated by signal kinase), and JNK (protein c-Jun N-terminal kinase) [34].

In contrast to BMP2, BMP 7 had a cytoprotective action for vascular proliferative disorders. In a coronary, carotid, and abdominal aorta in a diabetes-enriched cohort with 920 subjects, the SNPs rs6127984, rs6123674, and rs6123678 of BMP7 were independently associated with lower VC [35]. This antagonistic action could be mediated by the existence of specific receptors, such as endoglin (a type III TGF receptor), which binds to BMP-2 and not to BMP-7 [33].

2.5. Osteocalcin $(O C)$. OC are vitamin K-dependent proteins, expressed by preosteoclasts and osteoclasts. Total OC includes both carboxylated osteocalcin ( $\mathrm{cOC}$ ), which has a high affinity for hydroxyapatite, located predominantly in the bone matrix, and undercarboxylated osteocalcin (ucOC), which represents between 40 and $60 \%$ of the total circulating osteocalcin. This protein was recently associated with metabolic and cardiovascular disorders [36, 37]. The role of OC in VC is controversial. A recent inflammatory protocol, demonstrated using interferon- $\gamma$ and tumor necrosis factor$\alpha$, was used to examine the acute $(24 \mathrm{hr})$ and chronic $(144 \mathrm{hr})$ effects of ucOCN in subcultured human aortic endothelial cells (HAECs) and VSMCs. The ucOCN did not affect inflammatory cytokine production, nor inflammatory signaling pathways in VSMCs or HAECs [38]. In another study, Saad et al. observed in elderly patients with metabolic syndrome that osteocalcin serum levels were negatively 
correlated with carotid atherosclerosis [37]. However, other works suggest the opposite idea.

An animal model with cultured C57BL/6 thoracic aorta revealed that calcification was correlated with increased expression of osteocalcin [39]. It is suggested that the mechanism by which OC promotes SMC differentiation and mineralization is mediated by the production of Sox9, Runx2, collagen type $\mathrm{X}$, and proteoglycans and stimulating glucose metabolism in vascular cells via hypoxia-inducible factor $1 \alpha$ (HIF-1 $\alpha$ ) [40]. Also, Flammer et al. showed that high levels of $\mathrm{CO}$ were strongly associated with unstable CAD [41].

\subsection{Receptor Activator of Nuclear Factor Kappa-B/ Receptor} Activator of Nuclear Factor Kappa-B Ligand (RANK/ $R A N K L)$. Growing evidence suggests that the binomial of RANK/RANKL may be important players in vascular calcification. RANK is present in atherosclerotic plaques and valvular heart disease. It is a type I membrane protein expressed on the surface of osteoclasts and is involved in their activation upon ligand (RANKL) binding. RANKL is a transmembrane protein, but a soluble form (soluble RANKL is sRANKL) also circulates in the blood. RANKL binds as a homotrimer to RANK on target cells $[42,43]$.

It has been demonstrated that RANKL stimulates vascular calcification by binding to RANK through the alternative NF- $\kappa \mathrm{B}$ pathway. Also it was indicated that RANK indirectly promoted vascular smooth muscle cell calcification by enhancing macrophage paracrine procalcific activity. This is achieved through the release of IL6 and TNFa binding of TNF receptor-associated factors (TRAFs 2, 5, and 6) to specific sites in the cytoplasmic domain of RANK $[42,43]$.

2.7. Nuclear Factor-Kappa B (NF- $\kappa B)$. Nuclear factor-kappa $\mathrm{B}(\mathrm{NF}-\kappa \mathrm{B})$ is an essential protein for cell proliferation and migration. The increase in NF- $\kappa \mathrm{B}$ expression in $\mathrm{VC}$ is mediated by multiple factors, the main one being TNF $\alpha$, which decreases the expression of ankylosis protein homolog $(\mathrm{ANKH})$. This is a transmembrane protein that controls the efflux of pyrophosphate cells [44]. Voelkl et al. showed that in vitro and in animal model under conditions of calcification, the serum- and glucocorticoid-inducible kinase 1 (SGK1) are powerful regulators of NF- $\kappa$ B activity [45]. Studies have also shown that the advanced glycation end products (AGEs) and their receptors (RAGEs) are involved in this process $[46,47]$.

$\mathrm{NF}-\kappa \mathrm{B}$ is a DNA-binding protein that contributes to the process of vascular calcification by multiple mechanisms. It triggers the transcription of TNF $\alpha$, IL1 $\beta$, and IL6, enables the action of the RANKL/RANK pathway, and can modulate the proinflammatory cascade in VSMCs when associated with the $\mathrm{WNT} / \beta$-catenin signaling pathway in response to hyperphosphatemia. It also promotes the calcification of VSMCs by the expression of msh homeobox 2 (MSX2) and, consequently, Runx2. Also, it increases the expression of tristetraprolin (TTP), a destabilizing RNA protein, and reduces the ANKH mRNA decreasing pyrophosphate levels in the extracellular space $[47,48]$.
2.8. Canonical Signaling Pathway: Wingless/Beta Catenin (Wnt/ $\beta$ Catenin). The $\mathrm{Wnt} / \beta$ catenin pathway is involved in a variety of physiological processes including tissue/organ differentiation, morphogenesis, and in many aspects in the development and progression of vascular lesions. This vascular injury includes endothelial dysfunction, macrophage activation, proliferation, and vascular smooth muscle cell migration. In adults, these glycoproteins take part of the key developmental and physiological processes, including cell proliferation, differentiation, migration, and apoptosis $[48,49]$.

The activation of the Wnt/ $\beta$-catenin pathway is the binding of a Wnt ligand from the extracellular environment to two transmembrane proteins: a Frizzled protein acting as the receptor and a low-density lipoprotein receptor-related protein 5 or $6(\mathrm{Lrp5} / 6)$ acting as a coreceptor [50]. It is established that this pathway is essential for the VSMC differentiation [51].

The Wnt/ $\beta$-catenin release is enhanced by the action of different mechanisms [25]. We can mention Msx2 suppresses the antagonist Dkk1 that interacts with the LRP5/6 coreceptor [52].

$\mathrm{WNT} / \beta$-catenin acts by stimulating the production of Runx2, the main CV factor, and consequently the Sp7 transcription factor (osterix) during hyperphosphatemia [53]. Also, it can participate even more in the calcification by induction of MMP2 and MMP9 in VSMCs and thus plays a crucial role in the progression of this phenomenon. [54].

2.9. Pentraxin 3 (PTX3). Pentraxin 3 (PTX3) is a member of the pentraxin family. It is produced primarily in the liver and vascular endothelial cells in response to TNF $\alpha$, IL-1, and IL6 [52-54]. It is also released by peripheral blood leukocytes, myeloid dendritic cells, smooth muscle cells, fibroblasts, adipocytes, chondrocytes, mesangial, and epithelial cells. It has been reported that PTX3 induces the expression of RANKL by human osteoblasts, promoting osteoclastogenesis in vitro culture system [52-55].

In a population-based study with apparently healthy adults from four ethnic groups, PTX3 was associated with CVD risk factors, subclinical CVD, CAC, and clinical CHD events. These associations were independent of CRP supporting the hypothesis that PTX3 reflects different aspects of atherosclerosis-related inflammation than CRP [56].

2.10. Vascular Calcification-Inhibiting Factors: Inorganic Pyrophosphate. Inorganic pyrophosphate ( $\mathrm{PPi}$ ) is the main known calcification inhibitor found in extracellular space [60]. The PPi is produced in VSMCs and transported from the intracellular to the extracellular environment by the membrane protein ANK (progressive ankylosis or ANKH) [25]. It also is produced in the liver through ATP-binding cassette subfamily C member 6 (ABCC6) protein [57].

$\mathrm{PPi}$ is hydrolyzed by ecto-nucleotide pyrophosphatase/ phosphodiesterases (ENPP1) and local tissue-nonspecific alkaline phosphatase (TNAP) promoting pathophysiological vascular calcification $[58,59]$. High extracellular phosphate, which is frequently present in CKD, diabetes, and aortic 
calcification, reduces the production of PPi by increasing the expression of ENPP1 and TNAP by inducing apoptosis of the VSMCs [25-60]. However, in other work, it was observed in experimental models that PPi synthesis increases in VSMCs during phosphate-induced calcification because of compensatory regulation of PPi extracellular metabolism [60].

2.11. Matrix Gla Protein (MGP). Matrix gla protein (MGP) is a protein phosphorylated and carboxylated by vitamin $\mathrm{K}$. It is synthesized in various cellular types (mesenchymal, vascular, and chondrocytes). The expression of the MGP gene can be regulated via various mechanisms that have the potential to become genomic biomarkers for the prediction of vascular calcification (VC) progression [61, 62].

MGP acts as a potent inhibitor of VC. The mechanism of action includes direct inhibition of calcium-phosphate precipitation, the formation of matrix vesicles (MVs), the formation of apoptotic bodies, and differentiation of VSMCs [55]. The specific action of MGP could be related to the functional inhibition of BMP 2 and BMP-4, which have a similar structure $[62,63]$.

2.12. Fetuin- $A(F-A)$. Strong evidence indicates that human vascular smooth muscle cells exposed to changes in the extracellular calcium and phosphorus concentration undergo phenotypic differentiation leading to calcification, especially in chronic kidney disease (CKD) [60, 64].

F-A is a plasma glycoprotein, which in adults is synthesized by the liver, is a circulating proteinaceous calcification inhibitor, being able to bind $\sim 100 \mathrm{Ca}^{2+}$ ions per molecule. When F-A is exposed to high calcium and phosphate concentrations, the molecules coalesce to form the primary calciprotein particles (CPPs) that contain amorphous calcium phosphate with a diameter of $50-100 \mathrm{~nm}$, and F-A keeps these particles in solution and prevents it from precipitation [47-65].

Observational studies have shown that serum F-A reduction was associated with higher overall mortality and CV in patients with CRD $[65,66]$. Mice deficient in F-A presented soft tissue calcification when treated with diets enriched with vitamin D or phosphorus. In a study with subjects without diabetes and without renal dysfunction undergoing cardiac catheterization, multivariate logistic regression analysis revealed that F-A levels were inversely correlated with the presence of coronary calcification (OR: $0.54,95 \% \mathrm{CI}, P=0.025)$. Similarly, low serum F-A levels were associated with greater severity of $\mathrm{CD}$ in a large multiethnic population without clinical CVD, regardless of traditional CV risk factors, gender, ethnicity, and renal function $[67,68]$.

The polymorphisms in the corresponding $\alpha 2$-HeremansSchmid glycoprotein gene (AHSG) were shown to be associated with F-A serum levels. In the Diabetes Heart Study, SNPs of this molecule were analyzed in 829 diabetic adults; after multivariate analysis, two SNPs in AHSG in the exon region 6-7, rs2593813 and rs2070632, showed a significant association with CAC [69]. However, in a recent study, the molecular analysis of the AHSG T256S gene variant (rs4918) was performed when individuals with zero CAC to 10 and those with $\mathrm{CAC}>10$ were compared, and there was no significant association with F-A [70].

2.13. Osteoprotegerin. OPG is a cytokine produced in the bone marrow derived from stromal cells. It acts on bone remodeling by inhibiting the binding of RANK to RANKL on the surface of osteoclasts and T lymphocytes [71]. The role in vascular calcification is not completely defined.

A protective action was proposed for the accelerated evolution of atherosclerosis in OPG knockout mice [72]. However, another study showed that a high level of OPG was associated with a moderate calcium score is high in diabetic individuals [73]. Findings suggest that OPG can be used as a disease marker, increasing the levels of this protein as a compensatory response to the loss of bone mass and vascular damage [74].

In a prospective study of 130 patients, Pessaro et al. showed that elevated RANKL levels were associated with CHD (OR 1.75 (95\% CI 1.04-2.94, $P=0.035$ ) [75]. Recently, Choe et al. analyzed genetic variations using SNPs representative of OPG (rs2073618), RANK (rs1805034), and RANKL (rs2073618) and investigated the association with atherosclerotic plaque instability assessed by cardiac catheterization. It was found that the non-TT genotype of rs9594782 RANKL SNP was an independent risk factor for the occurrence of acute coronary syndrome [76].

2.14. Dickkopf Proteins (Dkk). The Dkk members include Dkk 1, 2, 3, and 4, among which only Dkk 1 is considered inhibitors of the canonical pathway Wnt/B-catenin, by blocking its interaction with coreceptors 5 and 6 of LDL (LRP5/6) [77]. Studies showed that Dkk-1 attenuates the expression of Runx2, which is a canonical Wnt target and an important transcription factor for the osteogenic transdifferentiation of VSMCs [53]. It has been suggested that high levels of Dkk-1 may contribute to the formation of unstable plaque by inhibiting the deposition of diffuse protective calcifications, in addition to influencing the cellular composition of the plaque [78].

Some studies related elevated serum levels of Dkk1 and the presence of VC by CAC [79]. Levels of Dkk-1 were also independently associated with a composite of cardiovascular death, myocardial infarction, or stroke and with cardiovascular death alone [80]. Fang et al. showed, in diabetic mice, with induced kidney disease, that the combination of Dkk1 neutralization and reduction of urinary phosphate by a phosphate ligand was sufficient to decrease vascular calcification [63].

2.15. Sclerostin. Protein that has been discovered in genetic studies of rare sclerosing bone dysplasias in humans is encoded by the SOST gene [81]. It is a 190 amino acid glycoprotein, a member of DAN proteins. Its structure consists of four different cysteine bonds synthesized by osteocytes with their gene expression also produced in the 
TABLE 1: Summary of vascular calcification mediators and their potential functions in promoting calcification.

\begin{tabular}{|c|c|c|c|}
\hline Protein & Gene & Function & Calcification \\
\hline IL- $1 \beta$ & IL1B (interleukin 1 beta) & $\begin{array}{c}\text { Proinflammatory cytokine which promotes } \\
\text { vascular calcification via NF- } \kappa \text { B and Wnt signaling } \\
\text { pathway }\end{array}$ & $\begin{array}{l}\text { Intima/ } \\
\text { media }\end{array}$ \\
\hline IL-6 & IL6 (interleukin 6) & $\begin{array}{c}\text { Proinflammatory cytokine which promotes } \\
\text { vascular calcification through inflammation- } \\
\text { induced oxidative stress. }\end{array}$ & $\begin{array}{l}\text { Intima/ } \\
\text { media }\end{array}$ \\
\hline $\begin{array}{l}\text { TNF } \alpha \text { (tumor necrosis factor } \\
\text { alpha) }\end{array}$ & TNF (tumor necrosis factor) & $\begin{array}{l}\text { Inflammatory cytokine which promotes vascular } \\
\text { calcification by increasing the expression of } \\
\text { osteogenic genes. }\end{array}$ & $\begin{array}{l}\text { Intima/ } \\
\text { media }\end{array}$ \\
\hline CRP & CRP (C-reactive protein) & $\begin{array}{l}\text { Proinflammatory protein may contribute to } \\
\text { vascular calcification through the raised expression } \\
\text { of osteogenic factors such as Runx } 2 \text { and TNAP. }\end{array}$ & $\begin{array}{l}\text { Intima/ } \\
\text { media }\end{array}$ \\
\hline $\begin{array}{l}\text { TNAP (tissue nonspecific } \\
\text { alkaline phosphatase) }\end{array}$ & ALPL (gene encoding human TNAP) & $\begin{array}{l}\text { Degrades inorganic pyrophosphate which makes } \\
\text { VSMCs susceptible to calcification }\end{array}$ & Media \\
\hline $\begin{array}{l}\text { Cbfa1/RUNX2 (RUNX } \\
\text { family transcription factor 2) }\end{array}$ & $\begin{array}{l}\text { RUNX2 (RUNX family transcription } \\
\text { factor 2) }\end{array}$ & $\begin{array}{c}\text { Transcription factor involved in chondrocyte and } \\
\text { osteoblast differentiation }\end{array}$ & Media \\
\hline Osterix & SP7 (Sp7 transcription factor) & $\begin{array}{c}\text { Controls the osteoblast differentiation and bone } \\
\text { formation }\end{array}$ & Media \\
\hline $\begin{array}{l}\text { BMP-2 (bone } \\
\text { morphogenetic protein 2) }\end{array}$ & BMP2 (bone morphogenetic protein 2) & $\begin{array}{l}\text { Osteogenic and osteoblast proliferation factor } \\
\text { which upregulates the expression of Runx2 }\end{array}$ & Media \\
\hline Osteocalcin & $\begin{array}{l}\text { BGLAP (bone gamma- } \\
\text { carboxyglutamate protein) }\end{array}$ & $\begin{array}{l}\text { Protein derived from osteoblasts, which stimulates } \\
\text { the PI3K/Akt signaling pathway and upregulating } \\
\text { the nuclear factor-kappa } \beta \text { (NF-K } \beta \text { ) }\end{array}$ & Media \\
\hline $\begin{array}{l}\text { RANKL (receptor activator } \\
\text { of nuclear factor kappa-B } \\
\text { ligand)> }\end{array}$ & TNFS11 (TNF superfamily member) & Regulates osteoclast differentiation and activation & $\begin{array}{r}\text { Media/ } \\
\text { intima }\end{array}$ \\
\hline $\begin{array}{l}\text { RANK (receptor activator of } \\
\text { nuclear factor kappa-B) }\end{array}$ & $\begin{array}{l}\text { TNFRSF11A (TNF receptor } \\
\text { superfamily member 11a) }\end{array}$ & $\begin{array}{l}\text { Activates the transcription factor NF- } \kappa \mathrm{B} \text { for the } \\
\text { generation and survival of osteoclasts }\end{array}$ & $\begin{array}{l}\text { Media/ } \\
\text { intima }\end{array}$ \\
\hline $\mathrm{NF}-\kappa \mathrm{B}$ & $\begin{array}{l}\text { NFKB (NF-kappa-B protein complex: } \\
\text { NFKB1, NFKB2, RELA, RELB, and } \\
\text { REL) }\end{array}$ & $\begin{array}{l}\text { Transcription factor which promotes vascular } \\
\text { calcification through the expression of MSX2 } \\
\text { (which increases TNAP expression) and reduces the } \\
\text { expression of ANKH through the expression of } \\
\text { tritetraproline }\end{array}$ & $\begin{array}{l}\text { Media/ } \\
\text { intima }\end{array}$ \\
\hline $\mathrm{Wnt} / \beta$-catenin & $\begin{array}{l}\text { WNT1/CTNNB1 (Wnt family member } \\
1 / \text { catenin beta } 1)\end{array}$ & $\begin{array}{l}\text { Through its canonical pathway promotes } \\
\text { osteogenic gene expression via nuclear } \beta \text {-catenin } \\
\text { dependent transcription }\end{array}$ & Media \\
\hline PTX3 & PTX3 (pentraxin 3) & $\begin{array}{l}\text { It has been reported that PTX3 induces the } \\
\text { expression of RANKL by human osteoblasts, } \\
\text { thereby promoting osteoclastogenesis in vitro } \\
\text { culture system }\end{array}$ & Media \\
\hline Inorganic pyrophosphate & - & $\begin{array}{c}\text { Prevents the nucleation of amorphous calcium } \\
\text { phosphate and inhibits hydroxyapatite } \\
\text { crystallization }\end{array}$ & Media \\
\hline ANKH & $\begin{array}{l}\text { ANKH (ankylosis, progressive } \\
\text { homolog) }\end{array}$ & $\begin{array}{c}\text { Inhibits mineralization by exporting inorganic } \\
\text { pyrophosphate to the extracellular space to inhibit } \\
\text { hydroxyapatite formation }\end{array}$ & Media \\
\hline Matrix gla protein & MGP (matrix gla protein) & $\begin{array}{l}\text { Inhibits vascular mineralization by binding to } \\
\text { calcium ions }\end{array}$ & Media \\
\hline Fetuin A & AHSG (alpha 2-HS glycoprotein) & $\begin{array}{c}\text { Inhibitor of calcification by binding to calcium ions } \\
\text { and forming calciprotein particles (CCPs) which } \\
\text { prevent the precipitation of amorphous calcium } \\
\text { phosphate particles }\end{array}$ & Media \\
\hline Osteoprotegerin & $\begin{array}{l}\text { TNFRSF11B (TNF receptor } \\
\text { superfamily member } 11 \mathrm{~b} \text { ) }\end{array}$ & $\begin{array}{l}\text { Binds to RANKL as a decoy receptor resulting in } \\
\text { down regulation of osteoclast differentiation, which } \\
\text { decreases osteoclast activity }\end{array}$ & $\begin{array}{l}\text { Media/ } \\
\text { intima }\end{array}$ \\
\hline $\begin{array}{l}\text { DKK1 (Dickkopf Wnt } \\
\text { signaling pathway inhibitor } \\
\text { 1) }\end{array}$ & $\begin{array}{l}\text { DKK1 (Dickkopf Wnt signaling } \\
\text { pathway inhibitor 1) }\end{array}$ & $\begin{array}{c}\text { Inhibitor of the canonical } \beta \text {-catenin-dependent } \\
\text { Wnt pathway, it was shown to reduce the } \\
\text { expression of Runx } 2 \text { which is a canonical Wnt } \\
\text { target }\end{array}$ & Media \\
\hline
\end{tabular}


TABLE 1: Continued.

\begin{tabular}{lcc}
\hline Protein & Gene & Function \\
\hline $\begin{array}{l}\text { LRP5/6 (LDL receptor- } \\
\text { related protein 5/6) }\end{array}$ & LRP5/6 (LDL receptor-related protein & $\begin{array}{c}\text { Wnt coreceptors that upon activation lead to } \\
\text { stabilization of cytoplasm } \beta \text {-catenin, nuclear } \\
\text { translocation, and target gene expression }\end{array}$ \\
Sclerostin & SOST (sclerostin) & $\begin{array}{c}\text { Inhibitor of Wnt/ } \beta \text {-catenin signaling, decreases } \\
\text { bone formation by inhibiting osteoblastogenesis, in } \\
\text { osteoclasts, and enhances bone resorption }\end{array}$ \\
Osteopontin & SPP1 (secreted phosphoprotein 1) & $\begin{array}{c}\text { Inhibitor of mineralization and ectopic calcification } \\
\text { linking the extracellular matrix with calcium }\end{array}$ \\
\hline
\end{tabular}

kidneys, liver, placenta, and cartilage. It binds to LRP (lowdensity lipoprotein receptor) 5 and 6 of the osteoblasts, inhibiting the Wnt pathway, which is a group of proteins that function as the genetic signaling of cell proliferation and the increase of osteoblastic activity and with antagonistic activity to BMP in the bone [81].

In vitro, sclerostin was expressed in the calcification process of vascular smooth muscle cells [74]. Recently, Nguyen-Yamamoto et al. showed in a mice model study that sclerostin protected the organism from VC by suppressing BMP2 production [82].

Elevated serum levels of this protein in individuals with chronic kidney disease were associated with a lower mortality rate, which leads to the hypothesis that sclerostin elevation is related to the protective function against vascular calcification [83].

2.16. Osteopontin $(O P)$. The role of OP in vascular calcification is still controversial; it is a protein that acts by binding to osteoclasts through avB3 integrin and stimulates calcium reabsorptive activity. It was found in calcified vascular tissue. In an experimental model, the protein inhibits the mineralization of vascular smooth muscle cells by direct binding to calcium crystals $[84,85]$. However, in a study by Benezin et al., 126 subjects with type $2 \mathrm{DM}$ and asymptomatic coronary artery disease, as determined by the CAC, the OP was an independent predictor of coronary calcification $(\mathrm{OR}=3.23,95 \% \mathrm{CI}=1.09-5.20 ; P=0.044)[86]$.

2.17. Genetics. In addition to chemical mediators, genetic characteristics and predisposition also play an important role in VC (Table 1).

A genome-wide association study (GWAS) reported a total of $31 \mathrm{DCV}$-associated loci at wide genomic significance $\left(P<5 \times 10^{-8}\right)$, accounting for only $10 \%$ of CVD heritability. This result may be explained probably because of the polygenic nature of the locus identified [8].

Data from the CARDIoGRAMplusC4D Consortium study, with 63,746 cases and 130,681 controls, identified 15 loci of genomic significance. Initially, six loci had relevant cardiovascular phenotypes, namely, ABCG8, APOB, GUCY1A3, PLG, LPL, and FES. PLG is adjacent to LPA, and the risk variant of PLG rs4252120 is strongly associated with elevated Lp(a) lipoprotein levels. Of the 30 loci of susceptibility to CAD previously reported in individuals of European and South Asian descent, PEMT, APOE, LDLR,
COL4A1, LIPA, APOA1 APOA5, PPAP2B, and PCSK9 also present phenotypic characteristics directly relevant to the disease [8].

Toutouzas et al. retrospectively evaluated coronary angiograms of patients with established $\mathrm{CAD}$ that were reinvestigated for stable/unstable angina. The $-174 \mathrm{C}$ allele of the IL- 6 gene has been shown to increase the risk of progression of coronary plaques over 4 years [65].

In another in vitro study, there was an overexpression of the cannabinoid receptor type 2 gene (CNR2), which is an inflammatory marker in atherosclerotic plaques, compared to normal arteries, but not exclusively in vulnerable plaques [66].

In a meta-analysis of broad exomic association, 25,109 European ancestors and African ancestors with $\mathrm{CD}$ and 52,869 participants using CAC and carotid medial-intimal thickening measured by ultrasonography found proteincoding variants in APOE $\varepsilon 2$. They were significantly associated with subclinical and clinical atherosclerosis, independently of ethnicity (odds ratio $0.77, P=1 \times 10^{-11}$ ) [87].

Chasman et al., in a cross-sectional study with white individuals, a polygenic risk score derived from an analysis of 50 SNPs that had genomic significance for association with coronary artery disease in previous studies and lifestyle were associated with CAC. The standardized CAC was 46 Agatston units (95\% CI, 39 to 54) among participants with high genetic risk, compared to CAC 21 Agatston units (95\% CI, 18 to 25$)$ among those with low genetic risk $(P<0.001)$. CAC was significantly higher among participants with an unfavorable lifestyle than among those with a favorable lifestyle: CAC 46 Agatston units (95\% CI, 40 to 53) versus CAC 28 Agatston units (95\% CI, 25 to 31$)(P<0.001)$ [88].

A recent systematic review of the literature with twelve studies showed that ADAMTS7 polymorphisms, especially SNP rs4380028 allele, have been consistently associated with CAD. ADAMTS7 rsrs4380028 was consistently related to coronary artery disease: both coronary artery calcification and coronary artery stenosis [89].

Van Setten et al. calculated polygenic scores based on SNPs with $P$ values reported by the CARDIoGRAMplusC4D2 consortium that reached a predefined threshold $\left(<5 \times 10^{-7}, \quad<5 \times 10^{-6}, \quad<5 \times 10^{-5}, \quad<5 \times 10^{-4}\right.$, $<5 \times 10^{-3},<0.05,<0.1,<0.2,<0.3,<0.4$, and $\left.<0.5\right)$, which resulted in 11 polygenic models containing between 39 and 15475 SNPs [8]. Later, they performed the association with EC in 2599 participants of the Dutch and Belgian Lung Cancer Screening (NELSON) trial. This polygenic model 
could explain up to $13.9 \%$ of the variance observed in CAC. This suggests that a substantial fraction of the hereditary risk for $\mathrm{CAD} / \mathrm{MI}$ is mediated by arterial calcification. Besides, it was observed that genetic variants associated with serum lipid levels and the body mass index influence the level of CAC [90].

Mendelian disorders are related to vascular calcification. For example, in genome-wide association, studies were able to identify loci at 6p21.3, 10q21.3, and 9p2 associated with CAC. It was also showed that ENPP1that encodes a cell surface protein that regulates extracellular phosphate is the gene responsible for idiopathic infantile arterial calcification (IIAC) [91].

Recently, mutations in the ABCC6 gene encoding a transmembrane ATP-binding protein were described in 14 of 28 children with IIAC and pseudoxanthoma elasticum. An animal model suggests that the ABCC6 gene is related to ectopic and vascular calcification. This calcification was attributed to reduced levels of $\gamma$-carboxylation of matrix gla protein (MGP), an important calcification inhibitor [91].

\section{Conclusion}

The VC has a complex pathophysiology still under investigation. The knowledge of the relationship of genetic factors with this process certainly becomes important, not only for the field of basic research but also for better definition of progression, prognosis, and provision of new therapies in the prevention and treatment of atherosclerosis. Future studies should better elucidate the mechanism involved in the pathophysiology and genetics of vascular calcification processes.

\section{Abbreviations}

$\begin{array}{ll}\text { CRF: } & \text { Cardiovascular risk factor } \\ \text { VSMC: } & \text { Vascular smooth muscle cell } \\ \text { CD: } & \text { Cardiovascular disease } \\ \text { VC: } & \text { Vascular calcification } \\ \text { CAC: } & \text { Coronary artery calcium } \\ \text { CI: } & \text { Confidence interval } \\ \text { IL: } & \text { Interleukin } \\ \text { IIAC: } & \text { Idiopathic infantile arterial calcification } \\ \text { TNF: } & \text { Tumor necrosis factor } \\ \text { oxLDL: } & \text { Oxidized low-density lipoprotein } \\ \text { HDL: } & \text { High-density lipoprotein } \\ \text { Anx: } & \text { Annexin } \\ \text { F-A: } & \text { Fetuin-A } \\ \text { Cbfa/Runx2: } & \text { Core-binding factor subunit 1 alpha/runt- } \\ & \text { related transcription factor 2 } \\ \text { RCP: } & \text { C-reactive protein } \\ \text { RANKL: } & \text { Receptor activator of nuclear factor } \\ \text { BMPs: } & \text { kappa- } \beta \text { ligand } \\ \text { MVs: } & \text { Bone morphogenetic proteins } \\ \text { OC: } & \text { Matrix vesicles } \\ \text { OP: } & \text { Osteocalcin } \\ \text { OPG/RANK/ } & \text { Osteopontin } \\ \text { RANKL: } & \text { Osteoprotegerin system-nuclear factor } \\ & \text { receptor kappa-B ligand }\end{array}$

$\begin{array}{ll}\text { PTX 3: } & \text { Pentraxin } 3 \\ \text { Wnt/ } \beta \text { Catenin: } & \text { Canonical signaling pathway Wingless/ } \\ & \text { beta catenin } \\ \text { DKK: } & \text { Dickkopf proteins } \\ \text { GWAS: } & \text { Genome-wide association study } \\ \text { Lp: } & \text { Lipoprotein } \\ \text { CNR2: } & \text { Cannabinoid receptor type } 2 \text { gene } \\ \text { SNPs: } & \text { Single nucleotide polymorphisms. }\end{array}$

\section{Conflicts of Interest}

The authors declare no conflicts of interest.

\section{Authors' Contributions}

L.F.E.G. and N.H.M.L. were responsible for conceptualization and original draft preparation. Reviewing and final editing were done by L.F.E.G., N.H.M.L., and C.A.E.G. N.H.M.L. performed critical reading and initiated and supervised the whole work.

\section{References}

[1] E. J. Benjamin, S. S. Virani, C. W. Callaway et al., "Heart disease and stroke statistics-2018 update: a report from the American Heart Association," Circulation, vol. 137, pp. 67492, 2018.

[2] J. N. Stabley and D. A. Towler, "Arterial calcification in diabetes mellitus," Arteriosclerosis, Thrombosis, and Vascular Biology, vol. 37, no. 2, pp. 205-217, 2017.

[3] J. M. Valdivielso, D. Rodríguez-Puyol, J. Pascual et al., "Atherosclerosis in chronic kidney disease," Arteriosclerosis, Thrombosis, and Vascular Biology, vol. 39, no. 10, pp. 19381966, 2019.

[4] D. E. Bild, G. Burke, k. Liu et al., "Coronary calcium as a predictor of coronary events in four racial or ethnic groups," New England Journal of Medicine, vol. 358, no. 13, pp. 1336-1345, 2008.

[5] A. E. Schantl, M. E. Ivarsson, and J.-C. Leroux, "Investigational pharmacological treatments for vascular calcification," Advanced Therapeutics, vol. 2, no. 1, p. 1800094, 2019.

[6] L. Zazzeroni, G. Faggioli, and G. Pasquinelli, "Mechanisms of arterial calcification: the role of matrix vesicles," European Journal of Vascular and Endovascular Surgery, vol. 55, no. 3, pp. 425-432, 2018.

[7] J. Ding, O. Ghali, P. Lencel et al., "TNF- $\alpha$ and IL- $1 \beta$ inhibit RUNX2 and collagen expression but increase alkaline phosphatase activity and mineralization in human mesenchymal stem cells," Life Sciences, vol. 84, no. 15-16, pp. 499-504, 2009.

[8] P. Deloukas, S. Kanoni, J. R. Thompson et al., "Large-scale association analysis identifies new risk loci for coronary artery disease," Nature Genetics, vol. 45, no. 1, pp. 25-33, 2012.

[9] B. H. Hahn, J. Grossman, W. Chen, and M. McMahon, "The pathogenesis of atherosclerosis in autoimmune rheumatic diseases: roles of inflammation and dyslipidemia," Journal of Autoimmunity, vol. 28, no. 2-3, pp. 69-75, 2007.

[10] R. D. Brook, S. Rajagopalan, C. Arden Pope et al., "Particulate matter air pollution and cardiovascular disease an update to the scientific statement from the american," Circulation, vol. 121, no. 21, 2010. 
[11] P. Lencel, S. Delplace, P. Pilet et al., "Cell-specific effects of TNF- $\alpha$ and IL- $1 \beta$ on alkaline phosphatase: implication for syndesmophyte formation and vascular calcification," Laboratory Investigation, vol. 91, no. 10, pp. 1434-1442, 2011.

[12] J. Kaminska, M. Stopinski, K. Mucha et al., "IL 6 but not TNF is linked to coronary artery calcification in patients with chronic kidney disease," Cytokine, vol. 120, pp. 9-14, 2019.

[13] M.-M. Zhao, M.-J. Xu, Y. Cai et al., "Mitochondrial reactive oxygen species promote p65 nuclear translocation mediating high-phosphate-induced vascular calcification in vitro and in vivo," Kidney International, vol. 79, no. 10, pp. 1071-1079, 2011.

[14] X. Zhang, J. Liu, X. Pang, J. Zhao, S. Wang, and D. Wu, "Aldosterone induces $\mathrm{C}$-reactive protein expression via MRROS-MAPK-NF- $\kappa$ B signal pathway in rat vascular smooth muscle cells," Molecular and Cellular Endocrinology, vol. 395, no. 1-2, pp. 61-68, 2014.

[15] L. A. Henze, T. T. D. Luong, B. Boehme et al., "Impact of C-reactive protein on osteo-/chondrogenic transdifferentiation and calcification of vascular smooth muscle cells," Aging, vol. 11, no. 15, pp. 5445-5462, 2019.

[16] P. Conti and Y. Shaik-dasthagirisaeb, "Atherosclerosis: a chronic inflammatory disease mediated by mast cells," Central European Journal of Immunology, vol. 3, no. 3, pp. 380-386, 2015.

[17] F. Parhami, B. Basseri, J. Hwang, Y. Tintut, and L. L Demer, "High-density lipoprotein regulates calcification of vascular cells," Circulation Research, vol. 91, no. 7, pp. 570-576, 2002.

[18] E. A. Fisher, J. E. Feig, B. Hewing, S. L. Hazen, and J. D. Smith, "High-density lipoprotein function, dysfunction, and reverse cholesterol transport," Arteriosclerosis, Thrombosis, and Vascular Biology, vol. 32, no. 12, pp. 2813-2820, 2012.

[19] E. Van der Pol, A. N. Böing, E. L. Gool, and R. Nieuwland, "Recent developments in the nomenclature, presence, isolation, detection and clinical impact of extracellular vesicles," Journal of Thrombosis and Haemostasis, vol. 14, no. 1, pp. 48-56, 2015.

[20] A. N. Kapustin, M. L. L. Chatrou, I. Drozdov et al., "Vascular smooth muscle cell calcification is mediated by regulated exosome secretion," Circulation Research, vol. 116, no. 8, pp. 1312-1323, 2015.

[21] C. Goettsch, J. D. Hutcheson, M. Aikawa et al., "Sortilin mediates vascular calcification via its recruitment into extracellular vesicles," Journal of Clinical Investigation, vol. 126, no. 4, pp. 1323-1336, 2016.

[22] V. Gerke, C. E. Creutz, and S. E. Moss, "Annexins: linking $\mathrm{Ca}^{2+}$ signalling to membrane dynamics," Nature Reviews Molecular Cell Biology, vol. 6, no. 6, pp. 449-461, 2005.

[23] A. N. Kapustin, J. D. Davies, J. L. Reynolds et al., "Calcium regulates key components of vascular smooth muscle cellderived matrix vesicles to enhance mineralization," Circulation Research, vol. 109, no. 1, pp. e1-12, 2011.

[24] J. F. Marchini, K. Croce, C. M. Shanahan et al., "Macrophagederived matrix vesicles," Circulation Research, vol. 113, no. 1, pp. 72-77, 2013.

[25] J. Voelkl, F. Lang, K.-U. Eckardt et al., "Signaling pathways involved in vascular smooth muscle cell calcification during hyperphosphatemia," Cellular and Molecular Life Sciences, vol. 76, no. 11, pp. 2077-2091, 2019.

[26] D. Ngai, M. Lino, and M. P. Bendeck, "Cell-matrix interactions and matricrine signaling in the pathogenesis of vascular calcification," Frontiers in Cardiovascular Medicine, vol. 5, p. $174,2018$.
[27] S. A. Steitz, M. Y. Speer, G. Curinga et al., "Smooth muscle cell phenotypic transition associated with calcification," Circulation Research, vol. 89, no. 12, pp. 1147-1154, 2001.

[28] J. B. Lian, G. S. Stein, A. Javed et al., "Networks and hubs for the transcriptional control of osteoblastogenesis," Reviews in Endocrine and Metabolic Disorders, vol. 7, no. 1-2, pp. 1-16, 2006.

[29] Z. Tang, A. Wang, F. Yuan et al., "Differentiation of multipotent vascular stem cells contributes to vascular diseases," Nature Communications, vol. 3, no. 1, p. 875, 2012.

[30] Y. Sun, C. H. Byon, K. Yuan et al., "Smooth muscle cellspecific runx2 deficiency inhibits vascular calcification," Circulation Research, vol. 111, no. 5, pp. 543-552, 2012.

[31] M.-E. Lin, T. M. Chen, M. C. Wallingford et al., "Runx2 deletion in smooth muscle cells inhibits vascular osteochondrogenesis and calcification but not atherosclerotic lesion formation," Cardiovascular Research, vol. 112, no. 2, pp. 606-616, 2016.

[32] N. Fukui, Y. Zhu, W. J. Maloney, J. Clohisy, and L. J. Sandell, "Stimulation OF BMP-2 expression BY pro-inflammatory cytokines IL-1 and TNF- $\alpha$ IN normal and osteoarthritic chondrocytes," The Journal of Bone and Joint SurgeryAmerican Volume, vol. 85, pp. 59-66, 2003.

[33] K. A. Hruska, S. Mathew, and G. Saab, "Bone morphogenetic proteins in vascular calcification," Circulation Research, vol. 97, no. 2, pp. 105-114, 2005.

[34] K. Miyazono, "Signal transduction by bone morphogenetic protein receptors: functional roles of Smad proteins," Bone, vol. 25, no. 1, pp. 91-93, 1999.

[35] B. I. Freedman, D. W. Bowden, J. T. Ziegler et al., "Bone morphogenetic protein 7 (BMP7) gene polymorphisms are associated with inverse relationships between vascular calcification and BMD: the diabetes heart study," Journal of Bone and Mineral Research, vol. 24, no. 10, pp. 1719-1727, 2009.

[36] A. Tacey, T. Qaradakhi, T. Brennan-Speranza, A. Hayes, A. Zulli, and I. Levinger, "Potential role for osteocalcin in the development of atherosclerosis and blood vessel disease," Nutrients, vol. 10, no. 10, p. 1426, 2018.

[37] C. R. Dhore, J. P. M. Cleutjens, E. Lutgens et al., "Differential expression of bone matrix regulatory proteins in human atherosclerotic plaques," Arteriosclerosis, Thrombosis, and Vascular Biology, vol. 21, no. 12, pp. 1998-2003, 2001.

[38] S. A. Millar, I. Zala, S. I. Anderson, and S. E. O'Sullivan, "Osteocalcin does not influence acute or chronic inflammation in human vascular cells," Journal of Cellular Physiology, vol. 235, no. 4, pp. 3414-3424, 2020.

[39] T. Akiyoshi, H. Ota, K. Iijima et al., "A novel organ culture model of aorta for vascular calcification," Atherosclerosis, vol. 244, pp. 51-58, 2016.

[40] A. Idelevich, Y. Rais, and E Monsonego-Ornan, "Bone Gla protein increases HIF- $1 \alpha$-dependent glucose metabolism and induces cartilage and vascular calcification," Arteriosclerosis, Thrombosis, and Vascular Biology, vol. 31, no. 9, 2011.

[41] A. J. Flammer, M. Gossl, R. J. Widmer et al., "Osteocalcin positive CD133+/CD34-/KDR+ progenitor cells as an independent marker for unstable atherosclerosis," European Heart Journal, vol. 33, no. 23, pp. 2963-2969, 2012.

[42] L. Rochette, A. Meloux, E. Rigal, M. Zeller, Y. Cottin, and C. Vergely, "The role of osteoprotegerin and its ligands in vascular function," International Journal of Molecular Sciences, vol. 20, no. 3, p. 705, 2019.

[43] M. Wu, C. Rementer, and C. M. Giachelli, "Vascular calcification: an update on mechanisms and challenges in 
treatment," Calcified Tissue International, vol. 93, no. 4, pp. 365-373, 2013.

[44] G. Zhao, M.-J. Xu, M.-M. Zhao et al., "Activation of nuclear factor-kappa B accelerates vascular calcification by inhibiting ankylosis protein homolog expression," Kidney International, vol. 82, no. 1, pp. 34-44, 2012.

[45] J. Voelkl, T. T. D. Luong, R. Tuffaha et al., "SGK1 induces vascular smooth muscle cell calcification through NF- $\kappa \mathrm{B}$ signaling," Journal of Clinical Investigation, vol. 128, no. 7, pp. 3024-3040, 2018.

[46] S. V. Suryavanshi and Y. A. Kulkarni, "NF- $\kappa \beta$ : a potential target in the management of vascular complications of diabetes," Frontiers in Pharmacology, vol. 8, pp. 1-12, 2017.

[47] A. M. Kay, C. L. Simpson, and J. A. Stewart Jr., "The role of AGE/RAGE signaling in diabetes-mediated vascular calcification," Journal of Diabetes Research, vol. 2016, p. 6809703, 2016.

[48] W. Matthijs Blankesteijn and K. C.M. Hermans, "Wnt signaling in atherosclerosis," European Journal of Pharmacology, vol. 763, pp. 122-130, 2015.

[49] S. Foulquier, E. P. Daskalopoulos, G. Lluri, K. C. M. Hermans, A. Deb, and W. M. Blankesteijn, "WNT signaling in cardiac and vascular disease," Pharmacological Reviews, vol. 70, no. 1, pp. $68-141,2018$.

[50] S. K. Bisson, R. V. Ung, and F. Mac-Way, "Role of the Wnt/ betacatenin pathway in renal osteodystrophy," International Journal of Endocrinology, vol. 2018, 2018.

[51] L. Yao, Y.-t. Sun, W. Sun et al., "High phosphorus level leads to aortic calcification via $\beta$-catenin in chronic kidney disease," American Journal of Nephrology, vol. 41, no. 1, pp. 28-36, 2015.

[52] F. Moalli, S. Jaillon, A. Inforzato et al., "Pathogen recognition by the long pentraxin PTX3," Journal of Biomedicine and Biotechnology, vol. 2011, Article ID 830421, 15 pages, 2011.

[53] T. Cai, D. Sun, Y. Duan et al., "WNT/ $\beta$-catenin signaling promotes VSMCs to osteogenic transdifferentiation and calcification through directly modulating Runx2 gene expression," Experimental Cell Research, vol. 345, no. 2, pp. 206-217, 2016.

[54] M. Klouche, G. Peri, C. Knabbe et al., "Modified atherogenic lipoproteins induce expression of pentraxin-3 by human vascular smooth muscle cells," Atherosclerosis, vol. 175, no. 2, pp. 221-228, 2004.

[55] G. D. Norata, P. Marchesi, V. K. Pulakazhi Venu et al., "Deficiency of the long pentraxin PTX3 promotes vascular inflammation and atherosclerosis," Circulation, vol. 120, p. $699708,2009$.

[56] N. S. Jenny, R. S. Blumenthal, R. A. Kronmal, J. I. Rotter, D. S. Siscovick, and B. M. Psaty, "Associations of pentraxin 3 with cardiovascular disease: the multi-ethnic study of atherosclerosis," Journal of Thrombosis and Haemostasis, vol. 12, no. 6, pp. 999-1005, 2014.

[57] R. S. Jansen, S. Duijst, S. Mahakena et al., "ABCC6-mediated ATP secretion by the liver is the main source of the mineralization inhibitor inorganic pyrophosphate in the systemic circulation-brief report," Arteriosclerosis, Thrombosis, and Vascular Biology, vol. 34, no. 9, pp. 1985-1989, 2014.

[58] A. Y. Savinov, M. Salehi, M. C. Yadav, I. Radichev, J. L. Millán, and O. V Savinova, "Transgenic overexpression of tissuenonspecific alkaline phosphatase (TNAP) in vascular endothelium results in generalized arterial calcification," Journal of the American Heart Association, vol. 4, no. 12, pp. 1-13, 2015.

[59] M. Bäck, T. Aranyi, M. L. Cancela et al., "Endogenous calcification inhibitors in the prevention of vascular calcification: a consensus statement from the cost action euro soft calc net," Frontiers in Cardiovascular Medicine, vol. 5, 2019.

[60] J. L. Reynolds, A. J. Joannides, J. N Skepper et al., "Human vascular smooth muscle cells undergo vesicle-mediated calcification in response to changes in extracellular calcium and phosphate concentrations: a potential mechanism for accelerated vascular calcification in ESRD," Journal of the American Society of Nephrology, vol. 15, no. 11, pp. 2857-2867, 2004.

[61] J. Wuyts and A. Dhondt, "The role of vitamin K in vascular calcification of patients with chronic kidney disease," Acta Clinica Belgica, vol. 71, no. 6, pp. 462-467, 2016.

[62] B. Geir, E. Svanberg, M. Dadar, and J David, "The role of matrix Gla protein (MGP) in vascular calcification," Current Medicinal Chemistry, vol. 25, p. 1, 2018.

[63] Y. Fang, C. Ginsberg, M. Seifert et al., "CKD-induced wingless/integration1 inhibitors and phosphorus cause the ckd-mineral and bone disorder," Journal of the American Society of Nephrology, vol. 25, no. 8, pp. 1760-1773, 2014.

[64] S. L. West, V. J. D. Swan, and S. A Jamal, "Effects of calcium on cardiovascular events in patients with kidney disease and in a healthy population," Clinical Journal of the American Society of Nephrology, vol. 5, no. 1, pp. 41-47, 2010.

[65] K. Toutouzas, D. Klettas, N. Anousakis-Vlachochristou et al., "The $-174 \mathrm{G}>\mathrm{C}$ interleukin-6 gene polymorphism is associated with angiographic progression of coronary artery disease over a 4-year period," Hellenic Journal of Cardiology, vol. 58, no. 1, pp. 80-86, 2017.

[66] R. Meletta, R. Slavik, L. Mu et al., "Cannabinoid receptor type 2 (CB2) as one of the candidate genes in human carotid plaque imaging: evaluation of the novel radiotracer [ $11 \mathrm{C}$ ]RS-016 targeting CB2 in atherosclerosis," Nuclear Medicine and Biology, vol. 47, pp. 31-43, 2017.

[67] C. Schäfer, A. Heiss, A. Schwarz et al., "The serum protein $\alpha 2$ Heremans-Schmid glycoprotein/fetuin-A is a systemically acting inhibitor of ectopic calcification," Journal of Clinical Investigation, vol. 112, no. 3, pp. 357-366, 2003.

[68] J. H. Ix, R. Katz, I. H. de Boer et al., "Fetuin-A is inversely associated with coronary artery calcification in communityliving persons: the multi-ethnic study of atherosclerosis," Clinical Chemistry, vol. 58, no. 5, pp. 887-895, 2012.

[69] A. B. Lehtinen, K. P. Burdon, J. P. Lewis et al., "Association of $\alpha 2$-heremans-schmid glycoprotein polymorphisms with subclinical atherosclerosis," The Journal of Clinical Endocrinology \& Metabolism, vol. 92, no. 1, pp. 345-352, 2007.

[70] C. Bellia, L. Agnello, B. Lo Sasso et al., "Fetuin-A is associated to serum calcium and AHSG T256S genotype but not to coronary artery calcification," Biochemical Genetics, vol. 54, no. 3, pp. 222-231, 2016.

[71] M. Schoppet, K. T. Preissner, and L. C. Hofbauer, "RANK ligand and osteoprotegerin," Arteriosclerosis, Thrombosis, and Vascular Biology, vol. 22, no. 4, pp. 549-553, 2002.

[72] W. J. Boyle, S. Kaufman, S. Morony et al., "Osteoprotegerin reverses osteoporosis by inhibiting endosteal osteoclasts and prevents vascular calcification by blocking a process resembling osteoclastogenesis," The Journal of Experimental Medicine, vol. 192, no. 4, pp. 463-474, 2002.

[73] D. V. Anand, A. Lahiri, E. Lim, D. Hopkins, and R. Corder, "The relationship between plasma osteoprotegerin levels and coronary artery calcification in uncomplicated type 2 diabetic subjects," Journal of the American College of Cardiology, vol. 47, no. 9, pp. 1850-1857, 2006.

[74] S. I. McFarlane, R. Muniyappa, J. J. Shin, G. Bahtiyar, and J. R. Sowers, "Osteoporosis and cardiovascular disease: brittle 
bones and boned arteries, is there a link?” Endocrine, vol. 23, no. 1, pp. 1-10, 2004.

[75] A. E. Pesaro, M. Katz, LibermanM et al., "Circulating osteogenic proteins are associated with coronary artery calcification and increase after myocardial infarction," PLoS One, vol. 13, no. 8, Article ID e0202738., 2018.

[76] W.-S. Choe, H.-L. Kim, J.-K. Han et al., "Association between OPG, RANK and RANKL gene polymorphisms and susceptibility to acute coronary syndrome in Korean population," Journal of Genetics, vol. 91, no. 1, pp. 87-89, 2012.

[77] K.-I. Kim, K. U. Park, E. J. Chun et al., "A novel biomarker of coronary atherosclerosis: serum DKK1 concentration correlates with coronary artery calcification and atherosclerotic plaques," Journal of Korean Medical Science, vol. 26, no. 9, pp. 1178-1184, 2011.

[78] R. Baetta and C. Banfi, "Dkk (dickkopf) proteins," Arteriosclerosis, Thrombosis, and Vascular Biology, vol. 39, no. 7, pp. 1330-1342, 2019.

[79] M. M. Schoos, P. Muntendam, M. J. Garcia et al., "Prevalence, impact, and predictive value of detecting subclinical coronary and carotid atherosclerosis in asymptomatic adults," Journal of the American College of Cardiology, vol. 65, no. 11, pp. 1065-1074, 2015.

[80] T. Ueland, A. Ålandai, T. Ghukasyan et al., "Admission levels of DKK1 (Dickkopf-1) are associated with future cardiovascular death in patients with acute coronary syndromes," Arteriosclerosis, Thrombosis, and Vascular Biology, vol. 39, no. 2, pp. 294-302, 2019.

[81] N. Kusu, J. Laurikkala, M. Imanishi et al., "Sclerostin is a novel secreted osteoclast-derived bone morphogenetic protein antagonist with unique ligand specificity," Journal of Biological Chemistry, vol. 278, no. 26, pp. 24113-24117, 2003.

[82] L. Nguyen-Yamamoto, K.-I. Tanaka, R. St-Arnaud, and D. Goltzman, "Vitamin D-regulated osteocytic sclerostin and BMP2 modulate uremic extraskeletal calcification," JCI Insight, vol. 4, no. 13, pp. 1-14, 2019.

[83] L. Viaene, G. J. Behets, K. Claes et al., "Sclerostin: another bone-related protein related to all-cause mortality in haemodialysis?" Nephrology Dialysis Transplantation, vol. 28, no. 12 , pp. 3024-3030, 2013.

[84] A. Miyauchi, J. Alvarez, E. M. Greenfield et al., "Recognition of osteopontin and related peptides by na alpha and beta 3 integrin stimulates immediate cells signals in osteoclast," Journal of Biological Chemistry, vol. 266, pp. 2369-2374, 1991.

[85] T. Wada, M. D. McKee, S. Steitz, and C. M. Giachelli, "Calcification of vascular smooth muscle cell cultures," Circulation Research, vol. 84, no. 2, pp. 166-178, 1999.

[86] A. E. Berezin and A. A. Kremzer, "Circulating osteopontin as a marker of early coronary vascular calcification in type two diabetes mellitus patients with known asymptomatic coronary artery disease," Atherosclerosis, vol. 229, no. 2, pp. 475-481, 2013.

[87] P. Natarajan, J. C. Bis, L. F. Bielak et al., "Multiethnic exomewide association study of subclinical atherosclerosis," Circulation: Cardiovascular Genetics, vol. 9, no. 6, pp. 511-520, 2016.

[88] D. I. Chasman, Ph D., U. Baber et al., "Genetic risk, adherence to a healthy lifestyle, and coronary disease," New England Journal of Medicine, vol. 375, no. 24, pp. 2349-2358, 2016.

[89] S. W. Rabkin and P. G Koitsopoulos, "Clinical genomics of the relationship between ADAMTS7 and coronary artery calcification and atherosclerosis," Journal of Translational Genetics and Genomics, vol. 2, p. 4, 2018.
[90] J. Van Setten, I. Išgum, S. Pechlivanis et al., "Serum lipid levels, body mass index, and their role in coronary artery calcification," Circulation: Cardiovascular Genetics, vol. 8, no. 2, pp. 327-333, 2015.

[91] M. A. Hofmann Bowman and E. M. McNally, "Genetic pathways of vascular calcification," Trends in Cardiovascular Medicine, vol. 22, no. 4, pp. 93-98, 2012. 